\title{
Comparison of Mid-term Functional Outcomes of Midshaft Clavicle Fractures: Conservative versus Surgical Treatment
}

\author{
Kayahan Karaytuğ ${ }^{1}$ (D) , Mehmet Ekinci ${ }^{2}$ (D) , Serkan Bayram³ ${ }^{3}$ (D) , Yusuf Bayram ${ }^{4}$ \\ Savaş Çamur $^{4}$ (D) , Sefa Giray Batıbay ${ }^{5}$ (iD , Mehmet Kapıcıoğlu ${ }^{6}$ (iD
}

'Department of Orthopedics and Traumatology, Acıbadem Maslak Hospital, Istanbul, Turkey

${ }^{2}$ Department of Orthopedics and Traumatology, Haseki Education and Research Hospital, Istanbul, Turkey ${ }^{3}$ Department of Orthopedics and Traumatology, Istanbul University, Istanbul Faculty of Medicine, Istanbul, Turkey

${ }^{4}$ Department of Orthopedics and Traumatology, Umraniye Education and Research Hospital, Istanbul, Turkey

${ }^{5}$ Department of Orthopedics and Traumatology, Ankara Occupational and Environmental Diseases Hospital, Ankara, Turkey

${ }^{6}$ Department of Orthopedics and Traumatology, Bezmialem Foundation University, Faculty of Medicine, Istanbul, Turkey

\section{Kayahan KARAYTUĞ}

Mehmet EKINCi

Serkan BAYRAM

Yusuf BAYRAM

Savaş ÇAMUR

Sefa Giray BATIBAY

Mehmet KAPICIOĞLU

Correspondence: Kayahan Karaytuğ Department of Orthopaedics and Traumatology, Acıbadem Maslak Hospital, Istanbul, Turkey Phone: +905366476944

E-mail: kayahan.karaytug@acibadem.com

$\begin{array}{ll}\text { Received } & : 09 \text { August } 2021 \\ \text { Accepted } & : 23 \text { September } 2021\end{array}$

\begin{abstract}
Purpose: The aim of the present study was to compare the mid-term functional outcomes of midshaft clavicle fracture between surgical and conservative treatment methods.

Methods: Forty-six patients with a mean age of 33.9 years and a mean follow-up period of 62.1 months were treated open reduction and plate fixation (group 1), whereas 52 patients with a mean age of 32.1 years and a mean follow-up period of 58.7 months were treated conservatively (group 2) between January 2013 and January 2018. The conservative group divided into two groups (group $2 A<2 \mathrm{~cm}$ and group $2 B \geq 2 \mathrm{~cm}$ shortening). The shortening was calculated as the difference between the lengths of the two clavicles on bilateral clavicle anteroposterior (AP) radiograph at final visit. Functional evaluation was performed with the University of California at Los Angeles(UCLA) Shoulder score, Constant score, and Disabilities of the Arm, Shoulder and Hand(DASH) score.
\end{abstract}

Results: No significant difference in age, gender, and follow-up duration was observed between two groups. The mean shortening in group 1 was $1.7 \pm 0.4 \mathrm{~mm}(0-2.8)$. The mean shortening in group 2 was $14.8 \pm 5.1 \mathrm{~mm}(7-24)$. There was no significant difference with respect to the DASH, Constant, and UCLA scores between two groups. However, there was a statistically significant difference between group $A(<2 \mathrm{~cm}$ shortening) and group $B(\geq 2 \mathrm{~cm}$ shortening) with respect to the DASH score.

Conclusions: DASH, UCLA and Constant scores in the conservative group and the surgically treated group were similar in our study.

Keywords: clavicle shortening, shoulder function, midshaft fracture, functional score

Klavikula Diafiz Kırıklarının Orta Dönem Fonksiyonel Sonuçlarının Karşılaştırılması: Konservatif vs Cerrahi Tedavi

ÖZET

Amaç: Çalışma middiafizer klavikula kırıkları nedeni ile cerrahi ve konservatif olarak tedavi edilen hastaların ortalama 5 yıllık takip süresi sonundaki fonksiyonel sonuçları karşılaştııılmıştır.

Yöntemler: 0cak 2013-0cak 2018 tarihleri arasında klavikula middiafizer kırıkları nedeni ile kayıtlı olan hastalar değerlendirildi. Ortalama yaşı 33.9 yıl olan 46 hasta açı redüksiyon ve plak fiksasyonu ile tedavi edildiği gözlendi (grup 1) ve ortalama takip süresinin 62,1 ay oldugu belirlendi. Ortalama yaşı 32.1 olan 52 hastaya ise konservatif tedavi uygulandı (grup 2). ortalama takip süresi 58,7 ay olarak belirlendi. Konservatif grup iki alt gruba ayrıldı (grup $2 \mathrm{~A}<2 \mathrm{~cm}$ ve grup $2 \mathrm{~B}$ $\geq 2 \mathrm{~cm}$ kısalma). Kaynama saptandıktan sonra çekilen bilateral klavikula ön-arka (AP) grafisi ile ölçüm yapılarak kısalma ölçümü yapıldı. Fonksiyonel değerlendirme University of California at Los Angeles(UCLA) Omuz skoru, Constant skoru ve Disabilities of the Arm, Shoulder and Hand(DASH) skoru ile yapıldı.

Bulgular: Íki grup arasında yaş, cinsiyet ve takip süresi açısından anlamlı fark gözlenmedi. Grup 1'de ortalama kısalma 1.7 $\pm 0.4 \mathrm{~mm}(0-2.8)$ idi. Grup 2'de ortalama kısalma 14,8 $\pm 5,1 \mathrm{~mm}(7-24)$ idi. DASH, Constant ve UCLA skorları açısından iki grup arasında anlamlı fark yoktu. Ancak grup A $(<2 \mathrm{~cm}$ kısalma) ve grup B ( $\geq 2 \mathrm{~cm}$ kısalma) arasında DASH skoru açısından istatistiksel olarak anlamlı fark vardı.

Sonuç: Konservatif grup ile cerrahi tedavi uygulanan grupta DASH, UCLA ve Constant skorları çalışmamızda benzerdi. kısalma arttıkça hasta raporlu sonuçların kötüleştiği gözlendi.

Anahtar kelimeler: köprücük kemiği kısalması, omuz fonksiyonu, orta şaft kırı̆̆ı, fonksiyonel skor 
lavicle fractures are common injuries, and up to $81 \%$ of these fractures are midshaft (1). Nonoperative treatment remains the main treatment for midshaft nondisplaced clavicular fractures $(2,3)$. Displaced midshaft clavicle fractures can be successfully treated both operatively and conservatively. However, the selection of surgical or conservative methods is still controversial (4).

Due to the axial skeleton is connected to the shoulder and the upper extremity with the clavicle, posttraumatic shortening may change the scapulothoracic movements and biomechanics, as well as the muscle tension and balance; this may reduce the functional results of the shoulder and acromioclavicular (AC) joint $(5,6)$. Different results were obtained in studies evaluating the relationship between clavicle shortening and shoulder functions. While some of the studies found no association between clavicle shortening and poorer functional outcomes $(7,8)$, a previous study stated that greater shortening causes more pain, complaints, and dissatisfaction (9). The aim of the present study was to compare the mid-term functional outcomes of midshaft clavicle fractures between surgical and conservative treatment.

\section{Patients \& Methods}

\subsection{Study Design}

This study was conducted in accordance with the ethical standards of the committee responsible for human experiments and the Declarations of Helsinki. The study was approved by the institutional review board (IRB Doc No. B.10.1.THK.4.34.H.GP.0.01). A total of 314 patients with clavicle midshaft fracture between the period of January 2013 and January 2018 were retrospectively determined from the hospital information system. Demographic data and clinical records were retrospectively examined to obtain patients' characteristics as well as information about the treatments of the patients. All fractures were classified according to the Neer classification (10), and type 1 (middle clavicle) fracture was selected for this study.

\subsection{Eligibility Criteria}

Patients diagnosed with acute clavicle midshaft fracture (within 14 days), minimum of 3 years of follow-up, and (3) available demographic and clinical data and patients with contralateral films of the clavicle were included in the study.

The exclusion criteria were: (1) patients $<18$ and $>70$ years old, (2) patients with chronic or sub-acute fractures (that occurred $>14$ days ago), (3) patients with open fracture, (4) patients with neurovascular injury, (5) patients with cognitive disorder, (6) patients with previous surgery in the affected clavicle or shoulder, (7) patients with pseudoarthrosis, and (8) patients with definite diagnosis of shoulder pathologies prior to trauma. A total of 98 (52 in the conservative group and 46 in the surgical group) patients were included in the study (Figure 1).
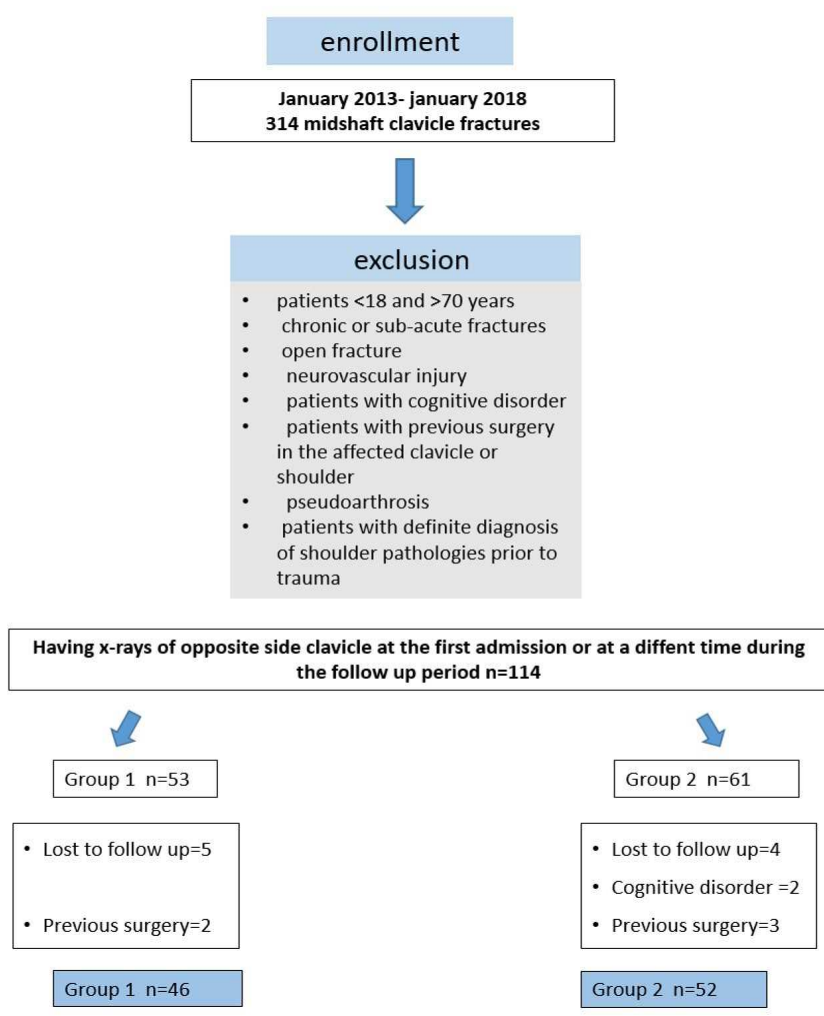

Fig. 1 Data collection and patient selection algorithm

\subsection{Treatment Protocol and Follow-up Management}

Patients in conservative group were treated with a clavicle bandage 6 weeks until radiological and especially clinical fracture healing is observed (group 1). Patients are referred to the physiotherapist for range of motion exercises in the fourth week of treatment. Strengthening exercises are started in the sixth week, and patients are advised to avoid contact sports for 4 months. The absolute operative treatment indications were displaced fracture with skin tenting and $\geq 2 \mathrm{~cm}$ shortening fractures. Patients with absolute indications were offered operative treatment but patients who didn't accept the surgical treatment or could not be operated because of different concomitant comorbidities or pathologies were treated conservatively. Open 
reduction and internal fixation (ORIF) is applied as standard with a 3.5-mm anatomical locking clavicle plate as the surgical technique (group 2). After the operation, patients use a sling for 3 weeks. As with conservative patients, patients are guided to the physiotherapist for movement exercises in the fourth week of treatment, strengthening is initiated at the sixth week, and patients are advised to avoid contact sports for 4 months.

\subsection{Radiological Evaluation}

Bilateral standard clavicle anteroposterior radiograph was obtained to evaluate the clavicle shortening. Both clavicles were measured from the center of the sternoclavicular joint to the center of the AC joint (Figure 2). The shortening was calculated as the difference between the lengths of the two clavicles. Both the primary (after initial trauma) and follow-up radiographs (after the union was completed) were examined for shortening, and the measurements were obtained in millimeters (9). All radiographic measurements were performed using a digital radiographic archiving system (GE pacs; GE Healthcare Systems, Barrington, USA) by three independent authors (KK, ME and SB).

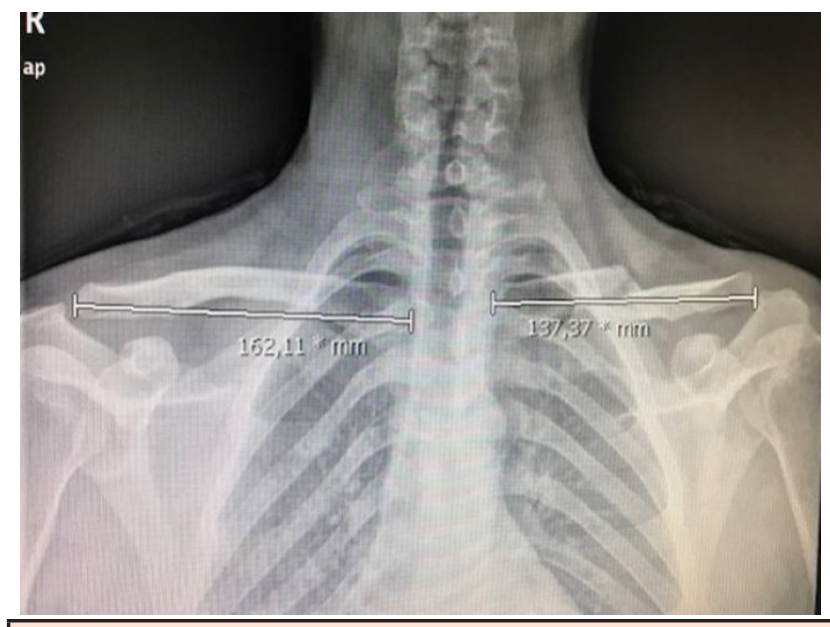

Fig. 2 Digital measurement of clavicle shortening on clavicular AP radiograph

\subsection{Functional Evaluation}

The patient-rated functional outcome was measured by the Quick Disabilities of the Arm, Shoulder, and Hand score, UCLA Shoulder Rating Scale score, and Constant score (11-13).

The radiological and functional evaluations were done at final follow-up visit.

\subsection{Statistically Analysis}

Statistical analyses were performed using IBM Statistical Package for Social Sciences for Windows, version 21.0 (IBM Corp., Armonk, NY, USA). Non-parametric Kruskal-Wallis $\mathrm{H}$ test was used for comparison of groups with non-normal distribution of data. The non-parametric Spearman's rank correlation test was used to calculate the correlation between the variables with non-normal data distribution. A p value $<0.05$ was considered to be statistically significant. Inter- and intraobserver reliability for radiographic measurements were assessed using the intraclass correlation coefficient (ICC). Each group was evaluated twice with repeat measurements on all radiographs with at least a oneweek interval for each measurement by 3 independent observers ( $\mathrm{KK}, \mathrm{ME}$ and $\mathrm{SB}$ ). Agreement was considered to be excellent for ICC values $>0.80$.

\section{Results}

In the current study, 98 patients $(\mathrm{n}=52$ in the conservative group and $n=46$ in the surgical group) were evaluated. There were 58 men and 40 women with a mean age of 32.5 (SD: 12.88) years. The age of the patients ranged from 18 to 69 years. The follow-up time ranged from 36 to 88 months, and the mean follow-up time for all patients was 62 (SD: 8.6) months (Table-1).

The mean DASH scores were $1.26 \pm 1.18$ in group 1 and $0.89 \pm 1.2$ in group 2 . The mean UCLA Shoulder rating scale scores were $32.8 \pm 2.7$ in group 1 and $33.8 \pm 3.2$ in group 2. The mean Constant scores were $96.2 \pm 3.1$ in group 1 and $97.3 \pm 4.2$ in group 2 . There was no significant difference with respect to the DASH score, Constant score, and UCLA score between two groups (Table-1).

All of the functional outcomes and radiological measurements had an ICC $>0.80$ (range 0.86 to 0.94 ), indicating good agreement on all parameters assessed by the three independent observers. The clavicle shortening in group 2 ranged from 7 to $24 \mathrm{~mm}$, and the mean value was $14.8 \pm$ $5.1 \mathrm{~mm}$. The range of shortening was $0-28 \mathrm{~mm}$ in group 1 , and the mean value was $17 \pm 4 \mathrm{~mm}(p<0.001)$. The conservative group was divided into two groups according to the amount of shortening in itself. Group $A(n=30)$ comprises patients with $<2 \mathrm{~cm}$ shortening, and group $B$ ( $n=$ 22 ) includes patients with $\geq 2 \mathrm{~cm}$ shortening. There was a statistically significant difference between group $A(<2 \mathrm{~cm}$ shortening) and group $B$ ( $\geq 2 \mathrm{~cm}$ shortening) with respect to the DASH score $(p=0.006)$. However, there was no significant difference with respect to the Constant score $(p=$ $0.183)$ and UCLA Shoulder rating scale score $(p=0.704)$. 
Table-1: Comparison of demographic and functional results of both groups.

\begin{tabular}{|c|c|c|c|c|c|}
\hline & \multicolumn{2}{|c|}{ Conservative Group } & \multicolumn{2}{|c|}{ Surgical Group } & \multirow[b]{2}{*}{$\mathrm{p}$ value } \\
\hline & Mean $\pm S D$ & Min - Max & Mean \pm SD & Min - Max & \\
\hline Age, years & $32.1 \pm 12$ & $20-69$ & $33.9 \pm 11$ & $18-66$ & 0.658 \\
\hline Gender, F/M & \multicolumn{2}{|c|}{$28 / 25$} & \multicolumn{2}{|c|}{$25 / 21$} & 0.418 \\
\hline Follow-up, months & $58.7 \pm 8$ & $36-74$ & $62.1 \pm 9$ & $36-88$ & 0.219 \\
\hline DASH Score & $0.89 \pm 1.2$ & $0-4.5$ & $1.26 \pm 1$ & $0-3.3$ & 0.825 \\
\hline UCLA score & $33.8 \pm 3.2$ & $25-40$ & $32.8 \pm 2.7$ & $30-40$ & 0.782 \\
\hline Constant Score & $97.3 \pm 4.2$ & $85-100$ & $96.2 \pm 3.1$ & $90-100$ & 0.912 \\
\hline Shortening, $\mathrm{mm}$ & $14.8 \pm 5.1$ & $7-24$ & $1.7 \pm 0.4$ & $0-2.8$ & $<0.001^{*}$ \\
\hline
\end{tabular}

\section{Discussion}

The effect of clavicle shortening on shoulder functional outcomes has not been clearly demonstrated in the literature (4). The Canadian Orthopaedic Trauma Society reported clavicle shortening to be associated with higher DASH scores (14); on the other hand, Virtanen et al. reported no significant difference between the functional outcome of the conservative and operative groups in their series (15). In the present study, within 5 years following treatment protocol, we found no statistical difference between the surgical and conservative groups with respect to the DASH, UCLA, and Constant scores.

It is declared that clavicle shortening is associated with poor functions. In addition, Hill et al. reported that a final shortening of $\geq 2 \mathrm{~cm}$ is associated with unsatisfactory results $(p<0.0001)$. Neither of the two studies was able to define the absolute value of clavicle shortening that was acceptable for good shoulder function $(4,14)$. In our study, there was a statistically significant difference between the conservative group $\mathrm{A}(<2 \mathrm{~cm}$ shortening) and group $\mathrm{B}(\geq 2$ $\mathrm{cm}$ shortening) with respect to the DASH score $(p=0.006)$. However, there was no significant difference with respect to the Constant score $(p=0.183)$ and UCLA Shoulder rating scale score $(p=0.704)$. The Canadian Orthopaedic Trauma Society and some other studies had reported significantly higher patient satisfaction in the operative group than in the conservative group $(14,16,17)$. In our study, patient satisfaction was similar in both groups (47/52 in the conservative group, 42/46 in the surgical group). In contrast to the studies we mentioned above, this finding is one of our results that differ from those reported by other studies. However, functional results may vary in situations where patient expectations differ. Satisfaction with this study may be similar as it was due to trauma, but it should be kept in mind that even minor shortnesses or rotations in elective situations will alter patient satisfaction.

Clavicle shortening was calculated by radiographs in most of the current studies. The major problem to calculate the shortening is the calibration of radiographs. Radiographs can be subject to error depending on the estimates made if the film is not calibrated (18). In addition to measuring the shortening directly, calculating the ratio of shortening to the length of the noninjured clavicle is another method. The main idea in this method is that the $2 \mathrm{~cm}$ threshold value will cause different biomechanical effects in the clavicle of different lengths. However, asymmetry of both clavicles may exist for individual cases. An asymmetry of $>5 \mathrm{~mm}$ in the clavicular length in $28.5 \%$ uninjured and skeletally mature adults was reported (19). Omid et al. measured shortening using computed tomography (CT) scans, which have been demonstrated to be a more accurate method of assessing fracture shortening than plain radiographs (20). The radiation dose of the shoulder CT scan is approximately 21 times higher than that of a flat chest radiograph (20). Although more accurate results are obtained from radiographs, CT scan is not routinely recommended for midshaft clavicle fractures due to higher radiation rates and the lack of a clear relationship between shortening and functional scores. In our cases, we measured the shortening with radiographs and compared the intact side to calculate the shortening of the clavicle by using digital radiographic archiving system. For the reasons mentioned above, our radiological measurement method can be considered as one of the limitations of the present study.

The clavicle is the only bone that binds the upper extremity to the thorax. Considering the origin and insertion 
regions of the shoulder girdle muscles, the shortening of the clavicle may cause a decrease in the strength of the shoulder muscles. The shortening of the clavicle causes increased sternoclavicular angle, which may reduce the range of overhead shoulder motion. It also changes the scapular position, and this may result in scapular dyskinesia as well as a change in the glenoid orientation-scapular rotation, which causes pain while the upper extremity is in motion $(3,21)$. The relationship between changed shoulder biomechanics caused by shortening of the clavicle and functional outcome remains a controversial subject. Some studies have found inferior functional outcome in the presence of clavicular shortening after healing $(5,7)$; on the contrary, another study has not demonstrated the existence of such a relationship (14). In our study, clavicle shortening had no statistically significant difference with respect to poorer functional outcomes. Teubner et al. proved that $1 \mathrm{~cm}$ shortening of the clavicle leads to a $40 \%$ more loading on the AC joint than usual, so arthritis becomes more likely (22). This result has been supported by some other studies showing abduction deficit and dysfunction in overhead mobility in patients with shortening of the clavicle (23). However, in asymptomatic patients, the prevalence of AC joint degeneration is reported to be between $48 \%$ and $82 \%$ in magnetic resonance imaging (24).

The current study has some limitations. Our study is a retrospective case series with a relatively small sample size. We did not evaluate functional scores before surgery or during treatment. On the other hand, scapulothoracic pathologies, silent AC joint degeneration, rotator cuff pathologies, or cervical disc pathologies that may occur simultaneously with the first trauma or at different times may also affect functional results in the long term. Making this distinction may yield more meaningful results, but the methodology of the study may not always be optimal in patients presenting with trauma. It should be kept in mind that all these shoulder-related pathologies can affect shoulder functional results as much as clavicle shortening.

\section{Conclusions}

After an average of 5 years of follow-up, the changes in DASH, UCLA and Constant scores in the conservative group and the surgically treated group were similar. However, the decrease of scores in cases with $\geq 2 \mathrm{~cm}$ predicts that providing the length of clavicle more successful functional results in the long term. Also, Satisfaction with this study may be similar as it was due to trauma, but it should be kept in mind that even minor shortnesses or rotations in elective situations will alter patient satisfaction.

Ethical Approval Section: This study was approved by our institutional review board (Istanbul Umraniye Training and Researh Hospital Ethic Committee).

\section{Approval Number: B.10.1.THK.4.34.H.GP.0.01/14}

Approval Date: 22.01.2020.

\section{References}

1. Su WR, Chen WL, Chen RH, et al. Evaluation of three-dimensional scapular kinematics and shoulder function in patients with short malunion of clavicle fractures. J Orthop Sci. 2016;21(6):739-44. doi:10.1016/j.jos.2016.07.005.

2. Ma X, Wang K, Ma J, et al. Operative treatments compared with nonoperative treatment of displaced midshaft clavicular fractures. J Orthop Sci. 2020;25(2):310-4. doi: 10.1016/j.jos.2019.04.002.

3. Goudie EB, Clement ND, Murray IR et al. The Influence of Shortening on Clinical Outcome in Healed Displaced Midshaft Clavicular Fractures after Nonoperative Treatment. J Bone Joint Surg Am. 2017;99(14):1166-72. doi: 10.2106/JBJS.16.01010.

4. Malik SS, Tahir M, Jordan RW, et al. Is shortening of displaced midshaft clavicle fractures associated with inferior clinical outcomes following nonoperative management? A systematic review. J Shoulder Elbow Surg. 2019;28(8):1626-38. doi: 10.1016/j.jse.2018.12.017.

5. Akgül T, Zehir S, Özdemir G, et al.[The results of low profile locking anatomical plate application for the treatment of Edinburg type 2 clavicle diaphysis fractures]. Ulus Travma Acil Cerrahi Derg. 2014;20(4):286-90. doi: 10.5505/tjtes.2014.88303.

6. Hillen RJ, Burger BJ, Pöll RG, et al. The effect of experimental shortening of the clavicle on shoulder kinematics. Clin Biomech. 2012;27(8):777-81. doi: 10.1016/j.clinbiomech.2012.05.003.

7. Veeger HEJ, van der Helm FCT. Shoulder function: The perfect compromise between mobility and stability. J Biomech. 2007;40(10):2119-29. doi:10.1016/j.jbiomech.2006.10.016.

8. Nowak J, Holgersson M, Larsson S. Can we predict long-term sequelae after fractures of the clavicle based on initial findings? A prospective study with nine to ten years of follow-up. J Shoulder Elbow Surg. 2004;13(5):479-86. doi: 10.1016/j.jse.2004.01.026.

9. Oroko PK, Buchan M, Winkler A, et al. Does shortening matter after clavicular fractures? Bull Hosp Jt Dis. 1999;58(1):6-8.

10. Lazarides S, Zafiropoulos $G$. Conservative treatment of fractures at the middle third of the clavicle: The relevance of shortening and clinical outcome. J Shoulder Elbow Surg. 2006;15(2):191-4. doi: 10.1016/j.jse.2005.08.007.

11. Kennedy $C A$, Beaton $D E$, Smith $P$, et al. Measurement properties of the QuickDASH (disabilities of the arm, shoulder and hand) outcome measure and cross-cultural adaptations of the QuickDASH: a systematic review. Qual Life Res. 2013;22(9):2509-47. doi: 10.1007/ s11136-013-0362-4.

12. Amstutz HC, Sew Hoy AL, Clarke IC. UCLA anatomic total shoulder arthroplasty. Clin Orthop Relat Res. 1981;155:7-20.

13. Conboy VB, Morris RW, Kiss J,et al. An evaluation of the constantMurley shoulder assessment. J Bone Joint Surg. 1996;78-B:229-32. 
14. Canadian Orthopaedic Trauma Society. Nonoperative treatment compared with plate fixation of displaced midshaft clavicular fractures. A multicenter, randomized clinical trial. J Bone Joint Surg Am. 2007;89:1-10. doi: 10.2106/JBJS.F.00020.

15. Virtanen KJ, Remes V, Pajarinen J, et al. Sling compared with plate osteosynthesis for treatment of displaced midshaft clavicular fractures: A randomized clinical trial. J Bone Joint Surg Am. 2012;94(17):1546-53. doi: 10.2106/JBJS.J.01999.

16. Woltz S, Krijnen P, Schipper IB. Mid-Term Patient Satisfaction and Residual Symptoms After Plate Fixation or Nonoperative Treatment for Displaced Midshaft Clavicular Fractures. J Orthop Trauma. 2018;32(11):e435-e439. doi: 10.1097/BOT.0000000000001269.

17. Figueiredo GSDL, Tamaoki MJS, Dragone B et al. Correlation of the degree of clavicle shortening after non-surgical treatment of midshaft fractures with upper limb function. BMC Musculoskelet Disord. 2015;16:151. doi: 10.1186/s12891-015-0585-3.

18. Malik A, Jazini $E$, Song $X$ et al. Positional change in displacement of midshaft clavicle fractures: an aid to initial evaluation. J Orthop Trauma. 2017;31(1):e9-e12. doi: 10.1097/BOT.0000000000000727.

19. Cunningham BP, McLaren $A$, Richardson $M$, et al. Clavicular length: The assumption of symmetry. Orthopedics. 2013;36(3):e343-7. doi: 10.3928/01477447-20130222-24.

20. Omid R, Kidd C, Yi A, et al. Measurement of clavicle fracture shortening using computed tomography and chest radiography. Clin Orthop Surg. 2016;8(4):367-372. doi: 10.4055/cios.2016.8.4.367.

21. Stegeman SA, de Witte PB, Boonstra $S$ et al. Posttraumatic midshaft clavicular shortening does not result in relevant functional outcome changes. Acta Orthop. 2015;86(5):545-52. doi: 10.3109/17453674.2015.1040982.

22. Teubner E, Gerstenberger F, Burgert R. [kinematic consideration of the shoulder girdle and its consequences on common surgical methods]. Unfallchirurg. 1991;94(9):471-7.

23. MullajiAB,Jupiter JB. Low-contact dynamic compression plating of the clavicle. Injury. 1994;25(1):41-5. doi: 10.1016/0020-1383(94)90183-x.

24 Özer M, Ataoğlu MB, Çetinkaya M, et al. Do intra-articular pathologies accompanying symptomatic acromioclavicular joint degeneration vary across age groups? Eklem Hastalik Cerrahisi. 2019;30(1):2-9. doi: 10.5606/ehc.2019.62431. 